\title{
Impact of Covid-19 on Islamic Stock Markets: An Investigation using Threshold Volatility and Event Study Models
}

Mohammad Irfan

Auro University, India

Corresponding email: Mohammad.irfan@aurouniversity.edu.in

Salina Kassim

International Islamic University Malaysia, Malaysia, ksalina@iium.edu.my

Sonali Dhimmar

Auro University, India, sonalidhimmar007@gmail.com

Article History

Received: November 30 3 th 2020 Revised: December 25 th, $2020 \quad$ Accepted: January $19^{\text {th }}, 2021$

\begin{abstract}
The Covid-19 is an unexpected event in the world history with substantial socioeconomic impact on the global economy. The global financial market was also badly affected as reflected by the extreme volatility as well as weak performances in the stock markets all over the world. How do the Islamic stock markets in various parts of the world behave during the Covid-19 shock? The objective of this study is to identify the impact of the Covid-19 pandemic as declared by the World Health Organization on the Islamic stock markets. Using the threshold volatility and event study models, the study analyses the impact of the Covid-19 announcement on the Islamic stock indices in the Indian Stock Exchange (represented by the Bombay Stock Exchange - BSE Shariah Index) and Indonesian Stock Exchange (represented by the Jakarta Islamic Indices - JII). With the date of event identified as $11^{\text {th }}$ March 2020, the event window consists of 60, 30 , and 20 days. The results show that the BSE Shariah and III have positive coefficients, with the BSE Shariah Index shows negative response to the announcement of Covid-19 as global pandemic. On the other hand, the JII reacted positively to the event. The study shows the reaction of a stock exchange is dependent on other economic factors unique to the country, resulting in the events impact of the Covid-19 to vary from one country to another.
\end{abstract}

Keywords: Covid-19, Stock Market, Volatility, Event Study, TARCH Model JEL Classifications: C13, C22, C53, G15

Type of paper: Research Paper

@ IJIEF 2021 published by Universitas Muhammadiyah Yogyakarta, Indonesia All rights reserved

DOI:

https://doi.org/10.18196/ijief.v4i1.10480
Web:

https://journal.umy.ac.id/index.php/ijief/article/view/10480

Citation:

Irfan, M., Kassim, S., \& Dhimmar, S. (2020) Impact of covid-19 on Islamic stock markets: An investigation using threshold volatility and event study models. International Journal of Is/amic Economics and Finance (IIIEF), 4(1), 121-148. DOI: https://doi.org/10.18196/ijief.v4i1.10480 
Irfan, Kassim, \& Dhimmar | Impact of Covid-19 on Islamic Stock Markets: An Investigation using Threshold Volatility and Event Study Models

\section{Introduction}

\subsection{Background}

The year 2020 started with an unprecedented event with the global economy being affected badly by the Novel Coronavirus (henceforth Covid-19) that disrupted whole economic activity. First identified in Wuhan, China in December 2019, the Covid-19 spread very fast and uncontrollably around the globe. The Covid-19 outbreak was termed as a 'black swan' because it was creating an unexpected economic difficulties and had a widespread effect on the whole world (Alali, 2020). On 30 th January 2020, the World Health Organization (WHO) announced the Covid-19 outbreak a Public Health Emergency of International Concern (PHEIC) (Panyagometh, 2020). On $11^{\text {th }}$ February 2020, the WHO named coronavirus disease COVID-19, and subsequently on $11^{\text {th }}$ March 2020, announced it as a global pandemic (Asia, 2020). The managing director of the International Monetary Fund, Kristalina Georgieva stated that "We anticipate the worst economic fallout since the Great Depression" (Toi, 2020). The Covid-19 is also classified as zoonotic as it can be transferred between people and animals (Kulal, 2020). The epidemic rapidly spread around the world. As of $13^{\text {th }}$ August 2020, there were greater than 20.6 million confirmed Covid-19 cases in 188 countries and more than 749,000 deaths reported (Panyagometh, 2020).

India was not spared from the impact of the Covid-19 pandemic. As the country with the second-largest population in the world, India has 176 million poor people, with the lowest rank in sanitation and medical amenities (Alam \& Chavali, 2020). The first Covid-19 case in India was identified on 30th January 2020 and spreading very rapidly with the current number of confirmed cases estimated at (World Health Organisation (WHO), 2020). Therefore, Covid-19 pandemic became an important concern for the Government of India. Prime Minister Narendra Modi declared 21 days countrywide lockdown on 24th March 2020, and further extended the lockdown period until $3^{\text {rd }}$ May 2020 as the situation further worsened. Similarly, the Covid-19 situation in Indonesia was also very bad. Indonesia reported its first two confirmed cases on $2^{\text {nd }}$ March 2020 (Alam \& Chavali, 2020). As the situation did not show any sign of receding, the President of Indonesia declared Covid-19 as national disaster on $13^{\text {th }}$ April 2020. By $1^{\text {st }}$ May 2020, Indonesia reported cases of more than 23,000 (Chong et al., 2020).

From a serious health crisis, the Covid-19 pandemic has resulted in an economic crisis that affected the world economic growth and societies as a whole (Panyagometh, 2020). The epidemic undoubtedly creates one of the biggest challenges ever confronted by humanitarian organization and global development as it gives indirect impact on political, economic \& social system (OECD, 2020). The outbreak of the Covid-19 pandemic has resulted in 
Irfan, Kassim, \& Dhimmar | Impact of Covid-19 on Islamic Stock Markets: An Investigation using Threshold Volatility and Event Study Models

significant economic fallout to the global economy, especially because China is the main exporter to many countries. Many countries depend on raw materials from China, thus this dependency has tremendously affected the global economic activity (Kulal, 2020). Economic disruptions due to the Covid19 have led to industrial output losses as well as job losses in many sectors. According to the International Monetary Fund (IMF) forecast, global growth is expected to decline by $6.3 \%$ in 2020. Likewise, the Organisation for Economic Cooperation and Development (OCED) expects a downturn in global economic growth by 1.5\%, while the Asian Development Bank (ADB) estimates the US \$4.1 trillion global costs of the Covid-19 pandemic, which is estimated to be more than forty times compared to the SARS pandemic cost in 2003. Moreover, the International Labour Organization predicts a 25 million increase in global unemployment (Khatatbeh et al., 2020).

Previous researches have shown that there exists strong relationship between key events including political events, geopolitical events, terrorist occurrences, environmental events, and disease outbreaks such as animal diseases, Ebola and SARS, with the financial markets, particularly the stock market returns (Bash, 2020). With the current large-scale nature of the Covid19 as shown by the total number of infected cases of $60,074,174$ and 1,416,292 deaths till $26^{\text {th }}$ November 2020 (WHO, November 2020), the global stock market shows a sound response to the world events. In the past when unexpected events occur share market investors are encouraged to exit from an unbalanced market. They are a move towards balanced and secure financial investment.

Therefore, the purpose of the study is to identify the impact of the Covid-19 event on the Islamic stock indices in the Indian and Indonesian stock market returns. Specifically, this study aims to achieve the following objectives:

- To conduct an event study of pre and post Covid-19 on the Islamic stock indices in the Indian Stock Exchange and Indonesian Stock Exchange;

- To measure the asymmetric threshold of Covid-19 new cases, and Covid-19 death cases on the Islamic stock indices in the Indian Stock Exchange and Indonesian Stock Exchange.

The paper is organized into five sections, consisting of the first introductory section. The second section starting with the background theory of the research and focus on the previous studies related to the topic. The second part describes the past studies that include previous events' impact on the selected stock market. The third section includes the research methodology applied in the study. The fourth section is concerned with the results and analyses of the study. It involves the findings of the research. The final section 
Irfan, Kassim, \& Dhimmar Impact of Covid-19 on Islamic Stock Markets: An Investigation using Threshold Volatility and Event Study Models

presents the conclusion and future recommendations. It defines a summary of the study and areas for further research.

\section{LITERATURE REVIEW}

\subsection{Background Theory}

In the stock market, new events frequently impacted on stockholders behaviour that directly affects stock prices. The previous event study-based research presented by Fama in 1969 was helpful in understanding of market reaction on selected particular events (Fama et al., 1969).

"A market in which prices always "fully reflect" available information is called efficient."

[Fama (1970)]

The concept of efficient market hypothesis presents three forms of the market. The weak form efficiency, semi-strong form efficiency and strong from efficiency. The weak form of EMH suggest that past performance of returns can't predict future price. It assumes that securities price reflects all public information of market but not shows new information which not yet available publicly. The semi-strong form assumes that price of securities adjusts rapidly to any new information which publicly available. The strong from of EMH recommended prices reflect both public \& private information (Jonsson \& Radeschnig, 2014). The past scenarios show many literatures based on event study impact on stock market prices. The event study is widely used by researcher in the area of Finance. It is become the common in business studies. The previous study includes the past events like Covid-19, global financial crisis, terrorist attack, elections, data breach disclosure, ban on the sale of restricted shares, stock market index composition changes, monetary policy execution, demonetization etc.

\subsection{Previous Studies}

In determining the impact of first recorded coronavirus case on Indian stock market, Bash (2020) analyses the Cumulative Average Abnormal Return (CAAR) of 30 countries. The results show that there is negative impact of Covid-19 on the stock market returns. The stock markets in these countries reacted negatively after first case if the Covid-19 was reported. (Khatatbeh et al., 2020) try to find Covid-19 impact on immediate response to infected countries. Results revealed that there was significant negative impact on 11 global share market indices. Alali (2020) examines the announcement of WHO regarding Covid-19 as a global pandemic and its impact on five biggest stock exchange. The study concludes that declaration of World Health Organization shows significant negative impact on returns of largest Asian share markets. 
Irfan, Kassim, \& Dhimmar | Impact of Covid-19 on Islamic Stock Markets: An Investigation using Threshold Volatility and Event Study Models

Kulal (2020) empirically identifies Covid-19 impact on Indian Stock Exchange using data from January 2, 2020 to January 22, 2020 of the NSE (National Stock Exchange). The result showed short-term downturn in stock market returns, and that there is significant effect of Covid-19 on the Indian stock market. Similarly, Alam \& Chavali (2020) describe the effect of Covid-19 lockdown period on the Indian stock market by applying the event study on 31 listed company in BSE.. The analyses on the 35 days event window consist of pre 20 days \& post 15 days data show significant positive response in event window period, with the stock market responded significantly during the lockdown period.

Chavali et al. (2020) identified event of elections impact on the share market. The election event of 2014 was studied. The period of the study consists of 2014 to 2019. Sample includes 31 listed companies of BSE. The 82 days event window defined result that market react positively on election event. It was drawn from the analyses that Efficient Market Hypothesis Semi-Strong from is true for emerging country like India. Tahir et al. (2020) elaborate event of terrorist attack on stock market of Pakistan. The data taken in the research was $1^{\text {st }}$ June 2014 to $31^{\text {st }}$ May 2017. The analyses of the research show significant long-term impact on stock market of Pakistan. Atsu \& Prasad (2020) examine data breach disclosure event on share market volatility. The data of S\&P 500 index of 96 companies revealed that there is significant difference in after and before breach disclosure. It stat that breach disclosure event has significant impact on equity market volatility.

Another important event that potentially affecting the global financial market is the US trade war with China. Setiawan et al. (2020) explore the impact of the US trade war with China on the Asian stock market returns. While the study showed that the market has positive returns before event, it recorded negative returns in the short-term event window. Finally, the study provides empirical evidence that market is efficient and stock prices reacts on information quickly. Alam \& Chavali (2020) investigates the Indian stock market and how it impacted in lockdown period due to Covid-19. The sample consist of 31 listed companies in BSE. The period of study is $24^{\text {th }}$ February 2020 to $17^{\text {th }}$ April 2020. The data revealed that there is significant positive response seen in the market. The stock market of India reacted well in lockdown period. Market \& Jung (2020) examine Korean Exchange performance in long-term horizon with empirical power and specification of test. The result found greatest empirical power in Korean Exchange. The simulation method gave result of best testing technique is mixture of Wilcoxon signed rank test with a book to market test. Liu (2020) investigate breaking news impact on stock market. In the short-term abnormal returns shows impact of hot news. It was also suggested from study that breaking news can help in pace with market performance. (Chaudhary et al., 2020) explore share market volatility in 
Irfan, Kassim, \& Dhimmar | Impact of Covid-19 on Islamic Stock Markets: An Investigation using Threshold Volatility and Event Study Models

Covid-19 situation. The indices of top 10 nations analysed by using GARCH model. The data period of the study consists of January 2019 to June 2020. The research concludes negative returns during Covid-19 period. The GARCH model shows significant positive impact for selected market indices. Meher et al. (2020) identify effect of Covid-19 on price variation in natural gas \& crude oil. The data collected from the period $1^{\text {st }}$ May 2017 to $30^{\text {th }}$ April 2020. The result suggests that there is significant effect of coronavirus pandemic on variation in natural gas \& crude oil prices. Shehzad et al. (2020) analyse stock market returns of US \& Japan and impact due to Covid-19. The result of GARCH model shows the impact for the S\&P 500, Nasdaq Composite Index, DAX 30, Nikkei 225, FTSE MIB, and SSEC.

Zhikun (2019) explores the impact on China's share market due to the ban on the sale of restricted shares. The outcomes recommend that the pressure formed by the announcement of the restricted stock has negative influence on the whole share market. (Skrinjaric, 2019) analysed the stock market index composition changes event on Zagreb Stock Market (ZSM) returns. The period of data is $2^{\text {nd }}$ January 2015 to $21^{\text {st }}$ March 2018. The research concludes negative impact of stock exclusion on Zagreb Stock Market returns. Additionally, it was also mentioned that stock market index composition changes impacted on ZSM retunes. Šafár \& Sini (2019) evaluate the announcement of QE federal reserve on the starting phase of market response. The result revealed that on the other day of declaration noted profits, the market shows positive response of announcement.

The study by Gok \& Dayi (2018) identified the association between share market returns with general elections of Turkish. The election period taken in the study was $1^{\text {st }}$ February 2020 to $31^{\text {st }}$ December 2017. The data analysed by GARCH model. The analyses declared that June 2015 election has a major negative effect on share market of Turkish. Nisar \& Yeung (2018) Aims to analyse association between variation in FTSE 100 with UK political sentiment. The results conclude that there is short-term relation between variations in stock market with public sentiment. It gives evidence that there is relationship exist between public mood and investors behaviour. Case (2018) empirically analyses association between Share markets with monetary policy executed by central bank of Brazil. The study declared that there is significant impact of implementation of monetary policy on stock market. In terms of Industry, financial sector is mostly affected.

Chauhan (2017) described the impact of demonetization on the Indian stock market. The data of S \& P Bombay Stock Exchange 100 companies was studied. The result found no significant effect of demonetization on stock exchange. It shows the short-term market fall because of some other reasons. Gunawardana (2017) observe the THAIFEX influence to share market in Thailand. Focusing on the food and beverage industry, the study finds that 
Irfan, Kassim, \& Dhimmar | Impact of Covid-19 on Islamic Stock Markets: An Investigation using Threshold Volatility and Event Study Models

semi-strong form of efficient market hypothesis does not hold true in terms of marketing event of exhibition. Jin et al. (2017) focused on financial market trends on significant returns of stock market. Using the Delta Naïve Bayes approach, the study finds that multisource predictions consistently outperform the single source predictions.

Katsikides et al. (2016) attempt to explore the association between stock market reaction and corporate social responsibility. The event used in the study is BP and Exxon oil spills, HSBC - money laundering; Barclays and Royal Bank of Scotland - Libor scandal. The analyses revealed that only HSBC event does not affect share market performance. In other four events stock market reacted significantly.

Pérez-rodríguez \& López-valcárcel (2012) studied impact of public info like process of research \& development in pharma on the valuation of the subsidizing company. Specifically, Sanofi-Aventis and its competitors Abbott and Roche were studied. The study revealed that there is no significant effect in the starting phase of news of R\&D process. It identified that news regarding safety warning had gave negative reaction on valuation of respective firm.

\section{METHODOLOGY}

\subsection{Data}

To reiterate, this study aims to analyse the impact of the Covid-19 global pandemic event on the performance of Indian Stock Exchange and Indonesian Stock Exchange. The research is empirical in nature and relies on secondary data sources. The Bombay Stock Exchange and Jakarta Stock Exchange selected for the study. The stock market data collected from BSE \& JSE official website.

The data analysed by using Event study methodology of research. The MS excel tool used by the researcher. The event day is $11^{\text {th }}$ March 2020 because on that day WHO declared Covid-19 as Global Pandemic. This day is taken as to. The analyses conducted for three event windows.

Table 1. Abbreviation of Indices

\begin{tabular}{lc}
\hline \multicolumn{1}{c}{ Symbols } & Indices \\
\hline BSE & Bombay Stock Exchange \\
BSE Shariah & BSE Shariah 500 Index \\
JSE & Jakarta Stock Exchange \\
JII & Jakarta Islamic Index \\
Cov-NC & Covid19-New Cases \\
Cov-DC & Covid19-New Death Cases \\
\hline
\end{tabular}

Sources: By Author's estimated 
Irfan, Kassim, \& Dhimmar | Impact of Covid-19 on Islamic Stock Markets: An Investigation using Threshold Volatility and Event Study Models

The three different event window is selected because the author wants to identify the variation in result in different time period. After that period the Lockdown was also declared in many places and virus spread very rapidly which panic humans' mind. That is the reason behind choosing three different event windows. The $1^{\text {st }}$ event window consists of 60 days. It includes 30 days pre \& 30 days post event data of BSE and JSE. The $2^{\text {nd }}$ event window has total 40 days. It means 20 days before and after event date data is collected. The 3 rd event window comprises 20 days. It contains pre \& post 10 days data from the event day. The short-term impact will easily be found from selected window \& the data collected. To investigate forecasting volatility for BSE, BSE Shariah, JSE, JII indices, Cov-NC and Cov-Dc. The study period covers from Jan 30, 2020, to Nov 3, 2020 long with all the time series daily data, because first covid19 case fallen on this date. The coronavirus new cases and death cases series of India and Indonesia collected from the Oxford Martin Programme on Global Development, which is a collaborative database of the University of Oxford researchers and Global Change Data Lab (Our World in Data Organization, 2020).

\subsection{Model Development}

\subsubsection{Event Study Methodology}

The event study methodology is very useful \& popular methods to identify effect of event on stock market returns. The event study method provides prediction of indices reaction on declaration of an event. The method is also fruitful to establish relationship between particular event with response of selected stock market. however, the previous study recommended the event study methodology as most suitable technique to evaluate cumulative average abnormal returns of pre \& post the declaration of an event. According to the data event window is made. The graphical representation of event window is presented in figure 1. 
Irfan, Kassim, \& Dhimmar | Impact of Covid-19 on Islamic Stock Markets: An Investigation using Threshold Volatility and Event Study Models

Figure 1. Event Study Timeline

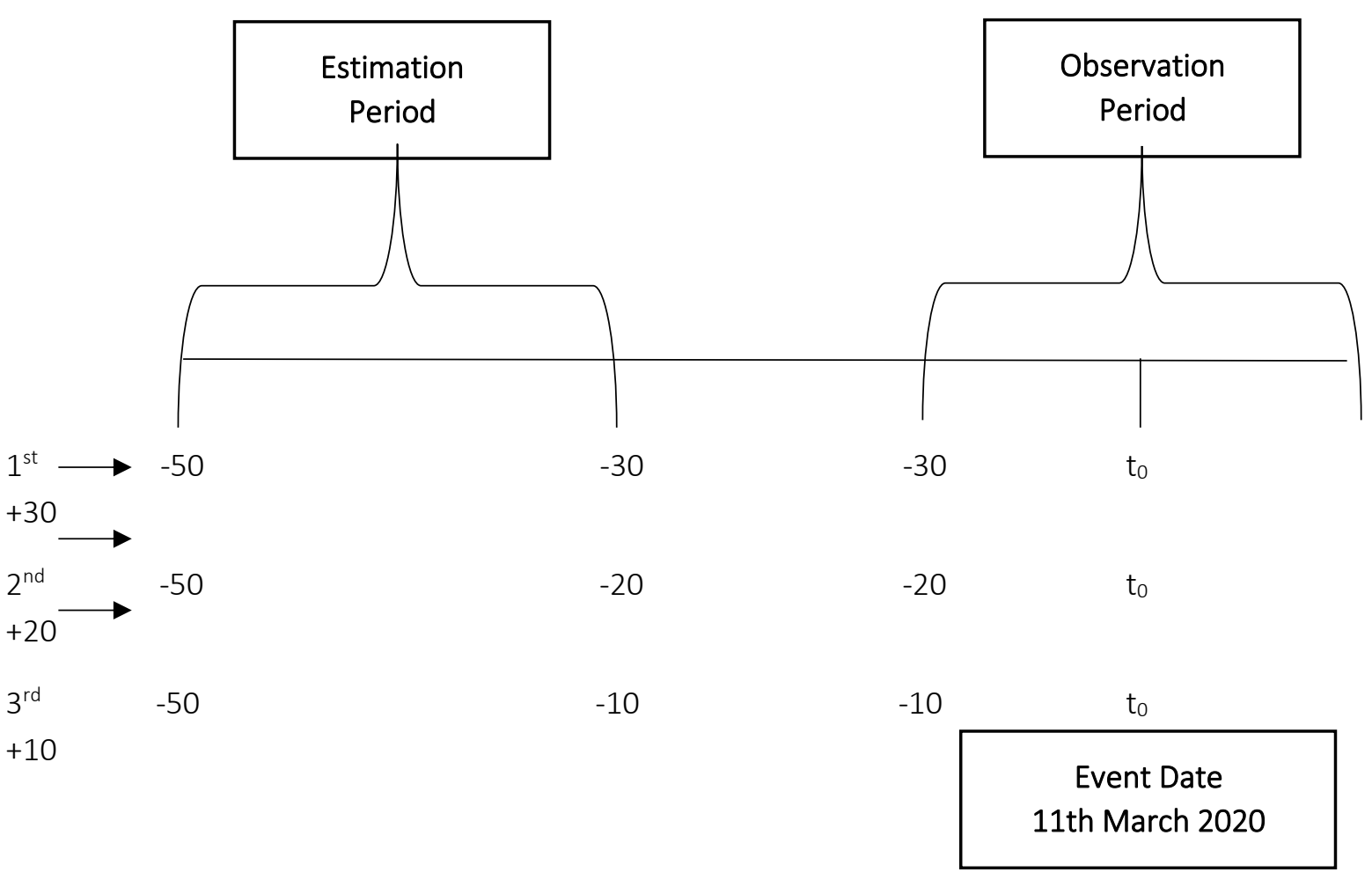

According to the event, window data is gathered from BSE \& JSE website. The estimation period of 50 days and observation period 30,20 and 10 days of pre \& post event data is clearly mention in the above chart. Further data is analysed by MS Excel using formulas of event methodology.

\subsubsection{Method}

In the every study focused on the methodology, because it will give clear picture on the objectives, The event study methodology describe below (RESEARCH, 2003) (Methodology et al., 2020).

First identify the returns of BSE \& JSE from respective data set. The formula for returns is:

$$
\text { "R } R_{t}=P_{1}-P_{0} / P_{0} "
$$

Second step includes the computation of Intercept, Slop, R-square and Standard Error using excel formulas. Then expected returns is computed. The formula for $E_{r}$ is:

"E $E_{r}=$ Intercept + Slop * Mkt. Return" 
Irfan, Kassim, \& Dhimmar | Impact of Covid-19 on Islamic Stock Markets: An Investigation using Threshold Volatility and Event Study Models

Then Average Return, Average Abnormal Return and Cumulative Average Abnormal Return is calculated. The formula is:

$$
\text { "AR } R_{t}=R_{t}-E_{r} "
$$

Where,

Rt $=$ Stock Return on given day

$\mathrm{Er}=$ Expected Return on given day

Based on Average return Average Abnormal Return and Cumulative Average Abnormal Return is computed. Further T-test in apply on CAAR to identify significant impact of event on respective stocks. The formula of T-test is:

"CAAR-T = Cumulative Average Abnormal Return / Standard Error"

The significant value of $t$ is 1.96 . The result of CAAR-t is comparing with significant t-value. If the value is greater than 1.96 then result is significant and if it is less than 1.96 then it is insignificant.

\section{ADF test}

ADF test has been used for the check the stationarity in the data, when ADFtest is significant (Irfan, 2020), p-value is less than $5 \%$ and t-test is more than the critical value, after check the stationarity, we go to the run ARCH test (Enders, 1995). After ADF-test is doing Arch family model (Ibrahim, 2019).

$$
" \Delta y_{t}=\alpha+\gamma y_{t-1}+\sum_{i=1}^{P} \Delta y_{t-i}+\varepsilon_{t} "
$$

Where $y_{t}$ data series is tested and $\gamma_{t-i}$ is the 1st difference in the tested series. Therefore, Ho: $\gamma=0$, is the null hypothesis to test the data series and $\mathrm{H} 1: \gamma<0$, is alternative hypothesis used to check the unit root test, meaning that it is non-stationary when the ADF test vale is less that critical value (Irfan, 2017),

\section{TARCH Model}

Arch family model has various different method to check the volatility in data from the different concept. Threshold-Garch method is extended version of Garch family model. It checked the leverage effect of bad and good news in the data series. T-Garch is also used for the asymmetric check (Brooks, 2008).

T-Garch model finds the negative news will be influence more than the good news, Zakoian (1990) and Glosten et al (1993). T-Garch have divided into two parts, mean variance and conditional variance, meaning that asymmetric response arrival of bad and good news (P.P. \& Deo, 2013). 
Irfan, Kassim, \& Dhimmar | Impact of Covid-19 on Islamic Stock Markets: An Investigation using Threshold Volatility and Event Study Models

The conditional variance is now given by:

$$
\text { " } \sigma_{t}^{2}=\omega+\sum_{j}^{p}=1 \beta_{j} \sigma_{t-j}^{2}+\sum_{i}^{q}=1 \alpha_{i} u_{t-i}^{2}+\sum_{k=1}^{r} \gamma_{k} u_{t-k}^{2} I_{t-k} "
$$

\section{RESULTS AND ANALYSIS}

The data analysis is a crucial part of the research. Here, the author interprets charts and tables that help in analyzing data. This part includes BSE and JII performance in the Covid-19 situation. The cumulative average abnormal returns and t-test justify the results. The presented graph shows movements in the Indian \& Indonesian stock prices. Further, ADF \& TARCH model represents its respective findings. It would give a clear explanation of market reaction in the pre-Covid event \& post-Covid event.

\subsection{Results}

\subsubsection{BSE Shariah Index - Results \& Interpretation of Event Study}

Table 2, describes the cumulative average abnormal returns for 60 days. It includes 30-day pre event market returns and 30-day post event market returns. The pre event window shows negative returns and post event window also found negative returns. The one thing noted from the table is that before the event the market is already showing downturn values and after the event the negative returns is increased tremendously. Overall, the table shows all the CAAR value in negative terms and T-stat also found negative. The data concludes that returns is significant in pre-post event period. It gives clear idea that Covid-19 event has gave some negative impact on BSE Sariah indices. 
Irfan, Kassim, \& Dhimmar | Impact of Covid-19 on Islamic Stock Markets: An Investigation using Threshold Volatility and Event Study Models

Table 2. Calculation of Cumulative Average Abnormal Return \& T- test (30 Day)

\begin{tabular}{|c|c|c|c|c|c|c|c|}
\hline \multicolumn{4}{|c|}{ Pre-Event Data } & \multicolumn{4}{|c|}{ Post-Event Data } \\
\hline Day & CAAR & CAAR-T & CAAR - T, Sig & Day & CAAR & CAAR-T & CAAR - T, Sig \\
\hline 30 & -1.171715712 & -398.8164025 & Yes & 1 & -1.62439 & -552.894 & Yes \\
\hline 29 & -1.173354808 & -399.3743009 & Yes & 2 & -1.6807 & -572.059 & Yes \\
\hline 28 & -1.180239247 & -401.7175547 & Yes & 3 & -1.7274 & -587.954 & Yes \\
\hline 27 & -1.193010736 & -406.0645812 & Yes & 4 & -1.78044 & -606.007 & Yes \\
\hline 26 & -1.192188862 & -405.7848402 & Yes & 5 & -1.85465 & -631.266 & Yes \\
\hline 25 & -1.193952506 & -406.3851309 & Yes & 6 & -1.90362 & -647.933 & Yes \\
\hline 24 & -1.198874947 & -408.0605802 & Yes & 7 & -1.96804 & -669.862 & Yes \\
\hline 23 & -1.207833783 & -411.1098957 & Yes & 8 & -2.01799 & -686.864 & Yes \\
\hline 22 & -1.210080046 & -411.8744552 & Yes & 9 & -2.086 & -710.01 & Yes \\
\hline 21 & -1.215098513 & -413.5825889 & Yes & 10 & -2.15828 & -734.613 & Yes \\
\hline 20 & -1.224105262 & -416.6482124 & Yes & 11 & -2.21057 & -752.411 & Yes \\
\hline 19 & -1.23308683 & -419.705265 & Yes & 12 & -2.25534 & -767.65 & Yes \\
\hline 18 & -1.237767852 & -421.2985427 & Yes & 13 & -2.30353 & -784.051 & Yes \\
\hline 17 & -1.246145765 & -424.1501296 & Yes & 14 & -2.35069 & -800.102 & Yes \\
\hline 16 & -1.256484818 & -427.6692288 & Yes & 15 & -2.38355 & -811.289 & Yes \\
\hline 15 & -1.267454741 & -431.4030569 & Yes & 16 & -2.40728 & -819.366 & Yes \\
\hline 14 & -1.275735491 & -434.2215725 & Yes & 17 & -2.43265 & -827.999 & Yes \\
\hline 13 & -1.286660609 & -437.9401506 & Yes & 18 & -2.453 & -834.927 & Yes \\
\hline 12 & -1.302053371 & -443.1793788 & Yes & 19 & -2.45474 & -835.52 & Yes \\
\hline 11 & -1.318840267 & -448.8931277 & Yes & 20 & -2.46007 & -837.334 & Yes \\
\hline 10 & -1.339880824 & -456.0546935 & Yes & 21 & -2.47929 & -843.877 & Yes \\
\hline 9 & -1.362306235 & -463.6876217 & Yes & 22 & -2.49975 & -850.838 & Yes \\
\hline 8 & -1.395117134 & -474.8554539 & Yes & 23 & -2.51744 & -856.859 & Yes \\
\hline 7 & -1.427329245 & -485.8194771 & Yes & 24 & -2.53537 & -862.963 & Yes \\
\hline 6 & -1.450929247 & -493.8522004 & Yes & 25 & -2.5537 & -869.201 & Yes \\
\hline 5 & -1.469551349 & -500.1905976 & Yes & 26 & -2.57382 & -876.051 & Yes \\
\hline 4 & -1.485084423 & -505.4775839 & Yes & 27 & -2.58868 & -881.109 & Yes \\
\hline 3 & -1.49607024 & -509.2168218 & Yes & 28 & -2.61629 & -890.505 & Yes \\
\hline 2 & -1.510282828 & -514.0543545 & Yes & 29 & -2.65138 & -902.449 & Yes \\
\hline 1 & -1.532697743 & -521.6837103 & Yes & 30 & -2.68365 & -913.433 & Yes \\
\hline
\end{tabular}

Source: Author's projected by Excel 
Irfan, Kassim, \& Dhimmar | Impact of Covid-19 on Islamic Stock Markets: An Investigation using Threshold Volatility and Event Study Models

Table 3. Calculation of Cumulative Average Abnormal Return \& T- test (20 Day)

\begin{tabular}{cccccccc}
\hline \multicolumn{3}{c}{ Pre-Event Data } & \multicolumn{3}{c}{ Post-Event Data } \\
\hline Day & CAAR & CAAR-T & CAAR -T, Sig & Day & CAAR & CAAR-T & CAAR -T, Sig \\
\hline 20 & -0.31093 & -89.7576 & Yes & 1 & -0.84899 & -245.082 & Yes \\
19 & -0.31398 & -90.6388 & Yes & 2 & -0.94145 & -271.775 & Yes \\
18 & -0.31347 & -90.4908 & Yes & 3 & -1.02791 & -296.733 & Yes \\
17 & -0.31767 & -91.7046 & Yes & 4 & -1.128 & -325.628 & Yes \\
16 & -0.32486 & -93.7799 & Yes & 5 & -1.25217 & -361.47 & Yes \\
15 & -0.33359 & -96.2985 & Yes & 6 & -1.34443 & -388.104 & Yes \\
14 & -0.33876 & -97.7904 & Yes & 7 & -1.46875 & -423.993 & Yes \\
13 & -0.34744 & -100.299 & Yes & 8 & -1.57573 & -454.877 & Yes \\
12 & -0.36343 & -104.914 & Yes & 9 & -1.68611 & -486.738 & Yes \\
11 & -0.38148 & -110.125 & Yes & 10 & -1.80172 & -520.112 & Yes \\
10 & -0.40541 & -117.032 & Yes & 11 & -1.90343 & -549.474 & Yes \\
9 & -0.43158 & -124.588 & Yes & 12 & -1.9936 & -575.503 & Yes \\
8 & -0.47304 & -136.556 & Yes & 13 & -2.09262 & -604.09 & Yes \\
7 & -0.51482 & -148.616 & Yes & 14 & -2.19397 & -633.347 & Yes \\
6 & -0.54686 & -157.865 & Yes & 15 & -2.27042 & -655.416 & Yes \\
5 & -0.57502 & -165.995 & Yes & 16 & -2.33886 & -675.173 & Yes \\
4 & -0.60032 & -173.299 & Yes & 17 & -2.40415 & -694.02 & Yes \\
3 & -0.62436 & -180.236 & Yes & 18 & -2.4667 & -712.077 & Yes \\
2 & -0.65839 & -190.061 & Yes & 19 & -2.51231 & -725.242 & Yes \\
1 & -0.70083 & -202.313 & Yes & 20 & -2.56102 & -739.304 & Yes \\
\hline
\end{tabular}

Source: Author's projected by Excel

Table 3, shows the T-test description as well as CAAR value. The data shows total 40 days analyses. The pre 20 days of event and post 20 days event data declares negative values. The before 20days of event returns is in minus term. After the event the market is became more volatile and the returns is decreased. The table shows the significant $t$ - values for all 40 days. The CAAR-t value describes Yes that indicates the result is significant in 40days event window. The analyses revealed significant impact on returns of BSE. It suggests that the declaration by WHO gave negative impact on BSE Sariah Index.

Table 4. Calculation of Cumulative Average Abnormal Return \& T- test (10 Day)

\begin{tabular}{cccccccc}
\hline \multicolumn{4}{c}{ Pre-Event Data } & \multicolumn{3}{c}{ Post Event Data } \\
\hline Day & CAAR & CAAR-T & CAAR-T, Sig & Day & CAAR & CAAR-T & CAAR -T, Sig \\
\hline 10 & 0.457105 & 131.1576 & Yes & 1 & 0.244834 & 70.25035 & Yes \\
9 & 0.449495 & 128.9741 & Yes & 2 & 0.178683 & 51.26976 & Yes \\
8 & 0.427818 & 122.7542 & Yes & 3 & 0.119422 & 34.26579 & Yes \\
7 & 0.405995 & 116.4925 & Yes & 4 & 0.048376 & 13.88058 & Yes \\
6 & 0.39354 & 112.9188 & Yes & 5 & -0.04605 & -13.2125 & Yes \\
5 & 0.385179 & 110.5197 & Yes & 6 & -0.1104 & -31.6769 & Yes \\
4 & 0.379668 & 108.9385 & Yes & 7 & -0.2025 & -58.1042 & Yes \\
3 & 0.376218 & 107.9486 & Yes & 8 & -0.2781 & -79.7945 & Yes \\
2 & 0.364481 & 104.5809 & Yes & 9 & -0.36102 & -103.587 & Yes \\
1 & 0.344318 & 98.79551 & Yes & 10 & -0.449 & -128.831 & Yes
\end{tabular}


Irfan, Kassim, \& Dhimmar | Impact of Covid-19 on Islamic Stock Markets: An Investigation using Threshold Volatility and Event Study Models

Table 4, revealed significant t-test value of cumulative average abnormal returns. The pre and post event data of 20 days presented above. The table describes pre vent CAAR returns in positive way but in decreasing terms. However, post event data shows downturn but positive returns for four days. On the $5^{\text {th }}$ day from the announcement table specifies negative returns. Day by day it is showing an increasing negative CAAR values. Inclusively the table conclude that in the 20 days of event window returns move towards positive to negative. The CAAR t-test value in "Yes" terms. It indicates that there is significant impact of Covid-19 event on Indian stock market.

\subsubsection{Jakarta Islamic Index- Results \& Interpretation of Event Study}

Table 5. Calculation of Cumulative Average Abnormal Return \& T- test (30 Day)

\begin{tabular}{|c|c|c|c|c|c|c|c|}
\hline \multicolumn{4}{|c|}{ Pre-Event Data } & \multicolumn{4}{|c|}{ Post Event Data } \\
\hline Day & CAAR & CAAR-T & CAAR -T, Sig & Day & CAAR & CAAR-T & CAAR -T, Sig \\
\hline 30 & 0.105532 & 30.21174 & Yes & 1 & 0.249719 & 71.48955 & Yes \\
\hline 29 & 0.108374 & 31.02541 & Yes & 2 & 0.288288 & 82.53085 & Yes \\
\hline 28 & 0.109744 & 31.41746 & Yes & 3 & 0.327738 & 93.82464 & Yes \\
\hline 27 & 0.113813 & 32.58244 & Yes & 4 & 0.365205 & 104.5509 & Yes \\
\hline 26 & 0.120097 & 34.38124 & Yes & 5 & 0.405981 & 116.2242 & Yes \\
\hline 25 & 0.124003 & 35.49944 & Yes & 6 & 0.479688 & 137.3249 & Yes \\
\hline 24 & 0.12841 & 36.76111 & Yes & 7 & 0.550834 & 157.6927 & Yes \\
\hline 23 & 0.126421 & 36.19171 & Yes & 8 & 0.617619 & 176.8116 & Yes \\
\hline 22 & 0.122604 & 35.09903 & Yes & 9 & 0.681227 & 195.0216 & Yes \\
\hline 21 & 0.11886 & 34.02722 & Yes & 10 & 0.735795 & 210.6431 & Yes \\
\hline 20 & 0.114556 & 32.79495 & Yes & 11 & 0.79043 & 226.284 & Yes \\
\hline 19 & 0.104667 & 29.96392 & Yes & 12 & 0.868081 & 248.5138 & Yes \\
\hline 18 & 0.087711 & 25.10992 & Yes & 13 & 0.948922 & 271.6571 & Yes \\
\hline 17 & 0.076238 & 21.82535 & Yes & 14 & 1.041864 & 298.2645 & Yes \\
\hline 16 & 0.063435 & 18.16016 & Yes & 15 & 1.125065 & 322.0833 & Yes \\
\hline 15 & 0.055147 & 15.78751 & Yes & 16 & 1.210518 & 346.5466 & Yes \\
\hline 14 & 0.046851 & 13.41249 & Yes & 17 & 1.3047 & 373.509 & Yes \\
\hline 13 & 0.042971 & 12.30173 & Yes & 18 & 1.401868 & 401.3261 & Yes \\
\hline 12 & 0.038943 & 11.14862 & Yes & 19 & 1.500203 & 429.4777 & Yes \\
\hline 11 & 0.031446 & 9.002469 & Yes & 20 & 1.599077 & 457.7831 & Yes \\
\hline 10 & 0.020137 & 5.764684 & Yes & 21 & 1.697393 & 485.9291 & Yes \\
\hline 9 & 0.020726 & 5.933406 & Yes & 22 & 1.796728 & 514.3668 & Yes \\
\hline 8 & 0.015783 & 4.518333 & Yes & 23 & 1.901358 & 544.32 & Yes \\
\hline 7 & 0.027675 & 7.92282 & Yes & 24 & 2.02136 & 578.6743 & Yes \\
\hline 6 & 0.03944 & 11.29093 & Yes & 25 & 2.150164 & 615.5482 & Yes \\
\hline 5 & 0.057751 & 16.53291 & Yes & 26 & 2.292459 & 656.2844 & Yes \\
\hline 4 & 0.077416 & 22.16258 & Yes & 27 & 2.438797 & 698.1778 & Yes \\
\hline 3 & 0.103132 & 29.5247 & Yes & 28 & 2.605082 & 745.782 & Yes \\
\hline 2 & 0.135956 & 38.92157 & Yes & 29 & 2.784277 & 797.0818 & Yes \\
\hline 1 & 0.166549 & 47.67968 & Yes & 30 & 2.952376 & 845.2051 & Yes \\
\hline
\end{tabular}

Source: Author's projected by Excel 
Irfan, Kassim, \& Dhimmar | Impact of Covid-19 on Islamic Stock Markets: An Investigation using Threshold Volatility and Event Study Models

Table 6. Calculation of Cumulative Average Abnormal Return \& T- test (20 Day)

\begin{tabular}{cccccccc}
\hline \multicolumn{4}{c}{ Pre-Event Data } & \multicolumn{5}{c}{ Post Event Data } \\
\hline Day & CAAR & CAAR-T & CAAR -T, Sig & Day & CAAR & CAAR-T & CAAR -T, Sig \\
\hline 20 & 0.307085 & 91.37815 & Yes & 1 & 0.455159 & 135.4399 & Yes \\
19 & 0.300693 & 89.47613 & Yes & 2 & 0.484064 & 144.041 & Yes \\
18 & 0.286862 & 85.36053 & Yes & 3 & 0.510573 & 151.9294 & Yes \\
17 & 0.278554 & 82.88831 & Yes & 4 & 0.533284 & 158.6873 & Yes \\
16 & 0.269021 & 80.05171 & Yes & 5 & 0.55588 & 165.4111 & Yes \\
15 & 0.264326 & 78.65459 & Yes & 6 & 0.612981 & 182.4024 & Yes \\
14 & 0.260202 & 77.4274 & Yes & 7 & 0.664305 & 197.6747 & Yes \\
13 & 0.260749 & 77.59009 & Yes & 8 & 0.710485 & 211.4163 & Yes \\
12 & 0.259703 & 77.27891 & Yes & 9 & 0.760486 & 226.295 & Yes \\
11 & 0.255055 & 75.89572 & Yes & 10 & 0.804769 & 239.4721 & Yes \\
10 & 0.245543 & 73.06525 & Yes & 11 & 0.847266 & 252.1176 & Yes \\
9 & 0.246205 & 73.26227 & Yes & 12 & 0.914784 & 272.2089 & Yes \\
8 & 0.240418 & 71.54032 & Yes & 13 & 0.984505 & 292.9554 & Yes \\
7 & 0.250429 & 74.51931 & Yes & 14 & 1.06881 & 318.0418 & Yes \\
6 & 0.262399 & 78.08109 & Yes & 15 & 1.145745 & 340.9351 & Yes \\
5 & 0.282626 & 84.09989 & Yes & 16 & 1.222878 & 363.8871 & Yes \\
4 & 0.304161 & 90.50812 & Yes & 17 & 1.309165 & 389.5634 & Yes \\
3 & 0.330171 & 98.24763 & Yes & 18 & 1.39817 & 416.0483 & Yes \\
2 & 0.358932 & 106.8061 & Yes & 19 & 1.488471 & 442.9188 & Yes \\
1 & 0.385789 & 114.7978 & Yes & 20 & 1.577282 & 469.3458 & Yes \\
\hline
\end{tabular}

Source: Author's projected by Excel

Table 5, explains the value of cumulative average abnormal return with t-test result of Jakarta stock exchange. The event window of 60 days period is analysed. It includes 30 days both before \& after data. The CAAR value around the selected window shows positive returns. Here, the pre event CAAR value is positive but volatile in nature. here it is shown that after the declaration the III returns is increased \& indicates positive upward movement in the market. The $t$ - test CAAR value is suggest that returns is significant. It is described from data that Jakarta stock market impacted by Covid-19 event.

Table 6, analyses t-test value of cumulative average abnormal value. It shows 40 days event window. The table indicates pre 20 days and post 20 days analyses. The table indicates that market was already gave positive returns before the announcement but there is some variation in the returns. After the declaration by WHO the returns are noted upward market movement \& reacted positively. The result declares the significant impact on the JII index. It mentions clear idea about Covid-19 impact on Indonesian stock market. 
Irfan, Kassim, \& Dhimmar | Impact of Covid-19 on Islamic Stock Markets: An Investigation using Threshold Volatility and Event Study Models

Table 7. Calculation of Cumulative Average Abnormal Return \& T- test (10 Day)

\begin{tabular}{cccccccc}
\hline & \multicolumn{2}{c}{ Pre-Event Data } & \multicolumn{4}{c}{ Post Event Data } \\
\hline Day & CAAR & CAAR-T & CAAR -T, Sig & Day & CAAR & CAAR-T & CAAR -T, Sig \\
\hline 10 & -0.05909 & -16.7121 & Yes & 1 & 0.298656 & 84.46866 & Yes \\
9 & -0.0492 & -13.9151 & Yes & 2 & 0.35408 & 100.1444 & Yes \\
8 & -0.04414 & -12.4848 & Yes & 3 & 0.412096 & 116.5529 & Yes \\
7 & -0.0215 & -6.08023 & Yes & 4 & 0.469213 & 132.7074 & Yes \\
6 & 0.000438 & 0.123833 & No & 5 & 0.53141 & 150.2985 & Yes \\
5 & 0.028497 & 8.059852 & Yes & 6 & 0.626174 & 177.1004 & Yes \\
4 & 0.058239 & 16.47177 & Yes & 7 & 0.72006 & 203.6543 & Yes \\
3 & 0.095016 & 26.87321 & Yes & 8 & 0.810227 & 229.1562 & Yes \\
2 & 0.141068 & 39.8983 & Yes & 9 & 0.89454 & 253.0023 & Yes \\
1 & 0.18506 & 52.34032 & Yes & 10 & 0.968701 & 273.9773 & Yes \\
\hline
\end{tabular}

Source: Author's projected by Excel

Table 7, explore the CAAR value as well as T-test for Jakarta stock market of 20 days event window. The before and after 10 days impact of Covid-19 is analysed. In the pre event window the returns are negative for few days. After it shows positive upgrading. After the event date the CAAR value is constantly improved or showing positive upward movement in the market. The T-test of CAAR identify significant impact of Covid-19 event. It shows that Jakarta stock market positively responded after the event declaration date.

Figure 2, presented pattern of behaviour of Bombay stock market and Jakarta stock exchange. The figure explains the market reaction in both before and after event day. The figure covered 60 days performance. It describes that BSE Sariah index \& JII index reacted differently on Covid-19 event. The Indian stock market shows downward sloping and Indonesian stock market describe upward sloping graph. It is stated from the pattern that the BSE Sariah's returns impacted negatively on Covid-19 event. Furthermore, the JII index has significant positive reaction of Covid-19 announcement.

Figure 2. Cumulative Average Abnormal Return of BSE \& Jakarta (30 Day)
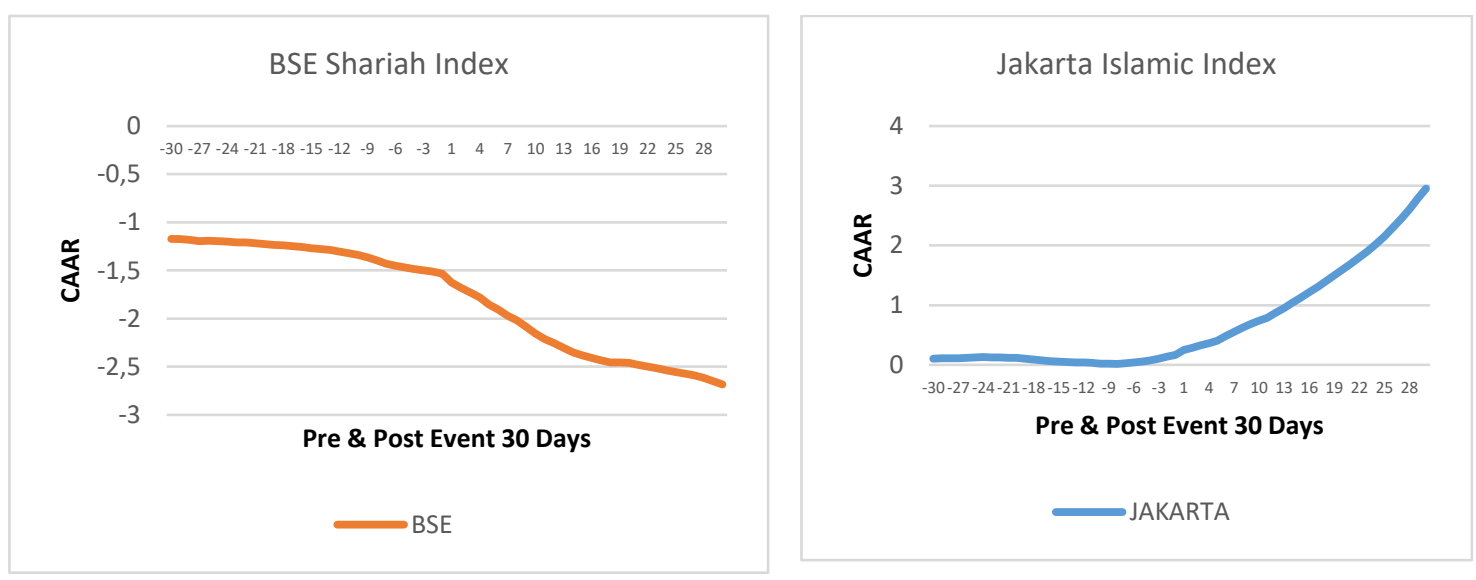

Source: Author's projected by Excel 
Irfan, Kassim, \& Dhimmar | Impact of Covid-19 on Islamic Stock Markets: An Investigation using Threshold Volatility and Event Study Models

Figure 3. Cumulative Average Abnormal Return of BSE \& Jakarta (20 Day)
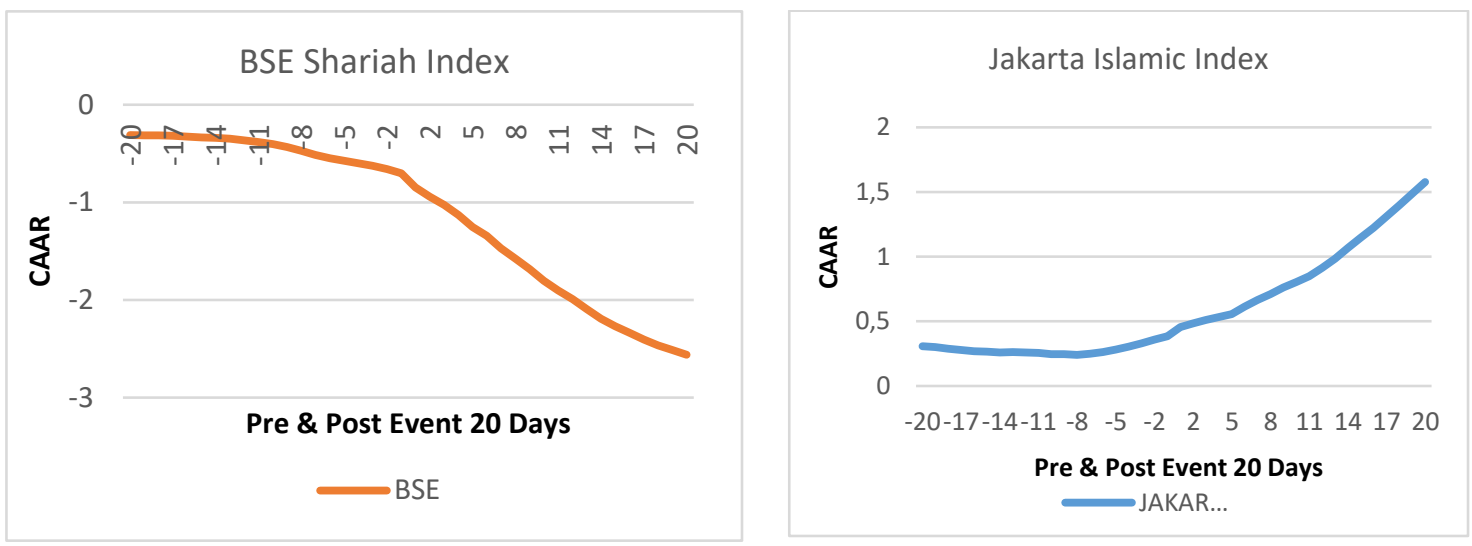

Source: Author's projected by Excel

Figure 3, plotted reaction of Indian \& Indonesian stock market returns. The 40 days event window show the BSE Sariah and JII reaction on Covid-19 event. It is describing that Covid-19 event give negative impact on Bombay stock market. The Jakarta stock exchange shows positive response to Covid-19 event. The stock market of both the country gave opposite reaction to the Covid-19 event. Finally, it is declared that the announcement by WHO lead to different impact for different countries stock market.

Figure 4 , explains the event window of pre \& post 10 days reaction of BSE Sariah index and JII index. The plot itself told the stock market reaction for both the countries. The Indian stock exchange index shows downward sloping after the Covid-19 event take place. The Indonesian Stock Exchange display upward sloping post Covid-19 event date. It clearly gives picture about BSE and JII response during pre \& post WHO announcement regarding Covid-19.

Figure 4. Cumulative Average Abnormal Return of BSE \& Jakarta (10 Day)
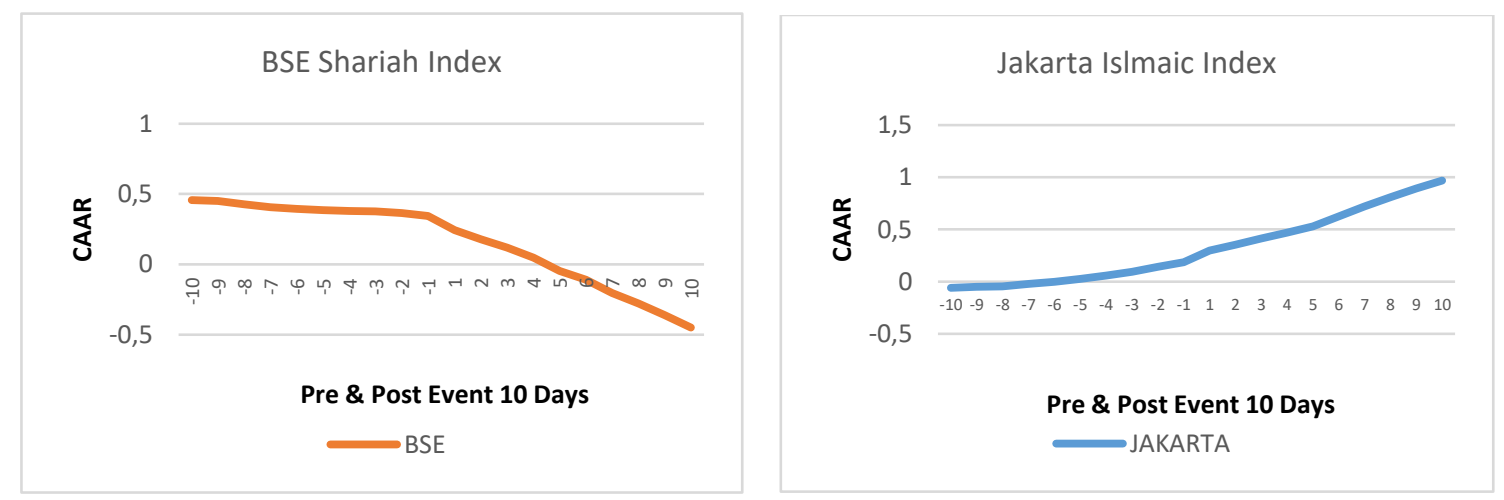

Source: Author's projected by Excel 
Irfan, Kassim, \& Dhimmar | Impact of Covid-19 on Islamic Stock Markets: An Investigation using Threshold Volatility and Event Study Models

Figure 5. Line Diagram of Indices and Variables

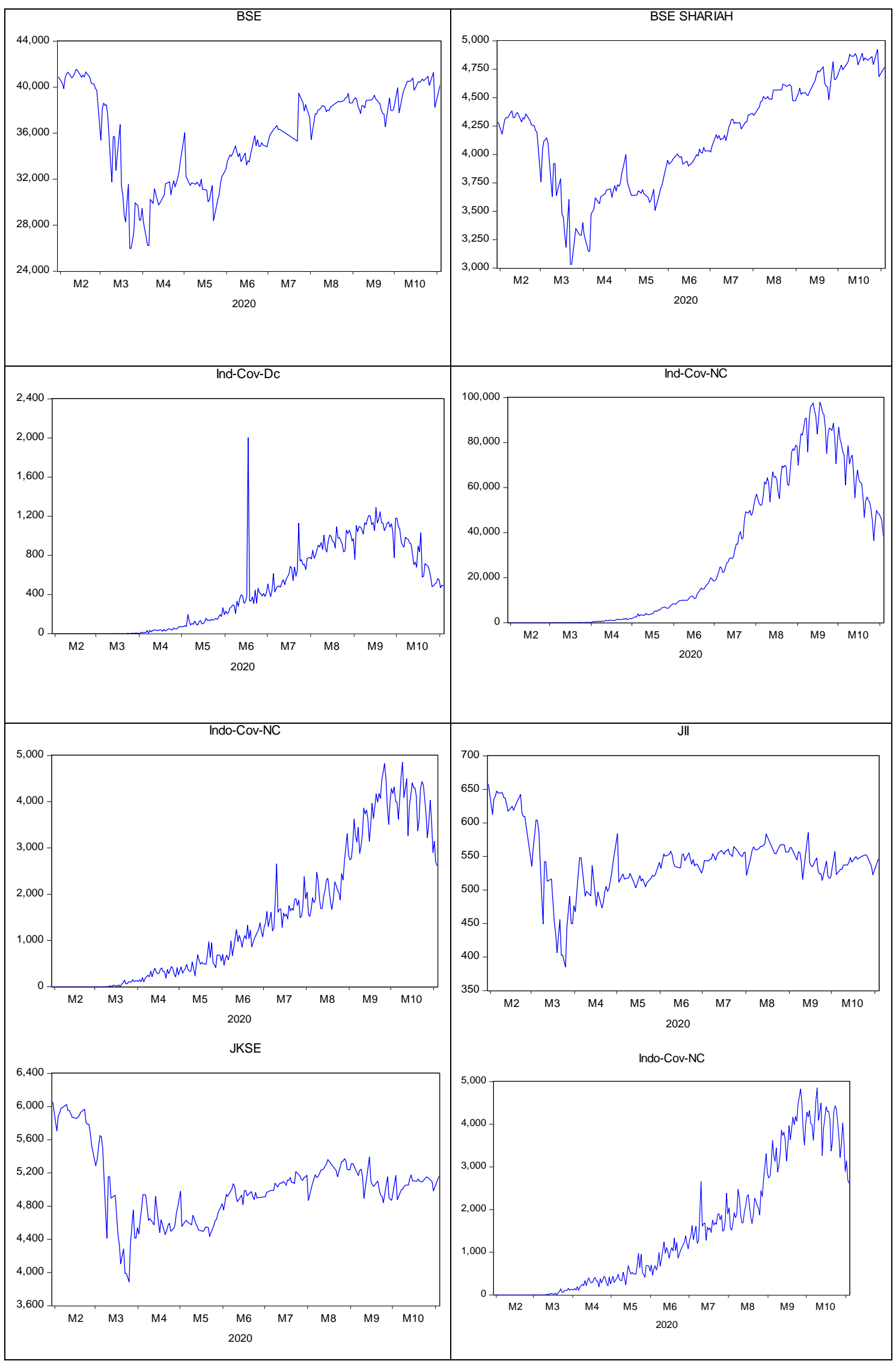


Irfan, Kassim, \& Dhimmar | Impact of Covid-19 on Islamic Stock Markets: An Investigation using Threshold Volatility and Event Study Models

\begin{tabular}{|l|l|}
\hline & \\
\hline
\end{tabular}

Figure 5, shows the line diagram of Indices and Variables. It shows upward \& downturn movements in the respective market. Through the graph, we can easily identify variability in the selected time.

Table 8, interpreted that the values of ADF test, -14.125 , which is less than its critical value, -1.215 , at $5 \%$, level of significance which implies that the all variables are stationary after the 1st difference (Irfan, 2016). The results of ADF test confirms that the other all the Shariah Indices and Cov-NC, Cov-DC are also stationary, because the values of ADF test statistic is less than its test critical value.

Table 9, An outcome of the TARCH model represent that the terms, C, are statistically significant in all the indices in conditionally mean equations. The variance equation describes that the $\operatorname{RESID}(-1)^{\wedge} 2$, which are statistically significant in BSE and JKSE indices, which imply that past volatility of BSE and JKSE indices are significantly not influencing current volatility. T-GARCH model is also confirming the coefficient positive significant at the $5 \%$ level. The analysis shows that there is a negative leverage effect of bad news has more than impact on conditional variance than good news. Here, Covid- New cases, Covid death cases are impacted due to coronavirus news spread in the market. Another diagnostic analysis is based on the different criteria like Akaike info criterion (AIC), Schwarz criterion (SIC), and Hannan-Quinn criteria (HQC), all these criteria have lower the value better will be results meaning that BSE Shariah, Jakarta Islamic index are lower values in comparison to the higher values of BSE and JKSE. At-last T-GArch model is more suitable for BSE Shariah and Jakarta Islamic indices. 
Table 8. ADF Test of Indices and Covid-19 variables

\begin{tabular}{|c|c|c|c|c|c|c|c|c|}
\hline Countries & Name of Variables & Level & t-test & P-value & coefficient & $1 \%$ level & $5 \%$ level & $10 \%$ leve \\
\hline \multirow[t]{4}{*}{ India } & Bombay Stock Exchange & & -14.125 & 0.000 & -1.215 & -3.454 & -2.872 & -2.572 \\
\hline & BSE Sharaih index & After 1st & -14.851 & 0.000 & -1.253 & -3.454 & -2.872 & -2.572 \\
\hline & India-Covid-New Cases & difference & -14.596 & 0.000 & -10.074 & -3.455 & -2.872 & -2.572 \\
\hline & India-Covid-New Death Cases & & -11.522 & 0.000 & -3.797 & -3.454 & -2.872 & -2.572 \\
\hline \multirow[t]{4}{*}{ Indonesia } & Jakarta Stock Exchange & & -12.096 & 0.000 & -1.253 & -3.454 & -2.872 & -2.572 \\
\hline & Jakarta Islamic Index & After 1st & -13.178 & 0.000 & -1.071 & -3.454 & -2.872 & -2.572 \\
\hline & India-Covid-New Cases & difference & -7.421 & 0.000 & -2.329 & -3.454 & -2.872 & -2.572 \\
\hline & India-Covid-New Death Cases & & -12.066 & 0.000 & -3.408 & -3.454 & -2.872 & -2.572 \\
\hline
\end{tabular}

Table 9. TARCH of Indices and Covid-19 variables

\begin{tabular}{|c|c|c|c|c|c|c|c|c|c|c|c|c|}
\hline \multicolumn{4}{|c|}{ BSE Sensex } & \multicolumn{3}{|c|}{ BSE Shariah } & \multicolumn{3}{|c|}{ Jakarta Stock Exchange } & \multicolumn{3}{|c|}{ Jakarta Islamic Index } \\
\hline Variable & COEF & z-Stat & Prob. & COEF & z-Stat & Prob. & COEF & z-Stat & Prob. & COEF & z-Stat & Prob. \\
\hline \multicolumn{13}{|c|}{ Conditional Mean Equation:- } \\
\hline $\mathrm{C}$ & 38456 & 188.90 & 0.00 & 4327 & 595.33 & 0.00 & 5050 & 329.42 & 0.00 & 549 & 372.04 & 0.00 \\
\hline \multicolumn{13}{|c|}{ Conditional Variance Equation:- } \\
\hline C & 1567362 & 6.631 & 0.000 & 764 & 2.164 & 0.031 & 170625 & 9.789 & 0.000 & 1440 & 14.925 & 0.000 \\
\hline $\operatorname{RESID}(-1)^{\wedge} 2$ & 0.580 & 1.467 & 0.142 & 1.143 & 3.005 & 0.003 & 0.360 & 1.236 & 0.216 & 0.549 & 3.531 & 0.000 \\
\hline Covid-New Cases & -143 & -2.398 & 0.017 & 2.779 & 4.520 & 0.000 & -30.740 & -5.176 & 0.000 & -0.240 & -12.136 & 0.000 \\
\hline Covid-New Death Cases & -1371 & -0.476 & 0.634 & -91.657 & -2.303 & 0.021 & -205.201 & -0.853 & 0.394 & -3.319 & -2.199 & 0.028 \\
\hline \multicolumn{13}{|l|}{ Diagnostic Statistics:- } \\
\hline Log likelihood & & & -2633 & & & -2017 & & & -2002 & & & -1359 \\
\hline Akaike info criterion & & & 18.910 & & & 14.500 & & & 14.388 & & & 9.779 \\
\hline Schwarz criterion & & & 18.976 & & & 14.565 & & & 14.453 & & & 9.844 \\
\hline Hannan-Quinn criter. & & & 18.937 & & & 14.526 & & & 14.414 & & & 9.805 \\
\hline
\end{tabular}


Figure 6. Residuals of Stock Exchange \& Its Index

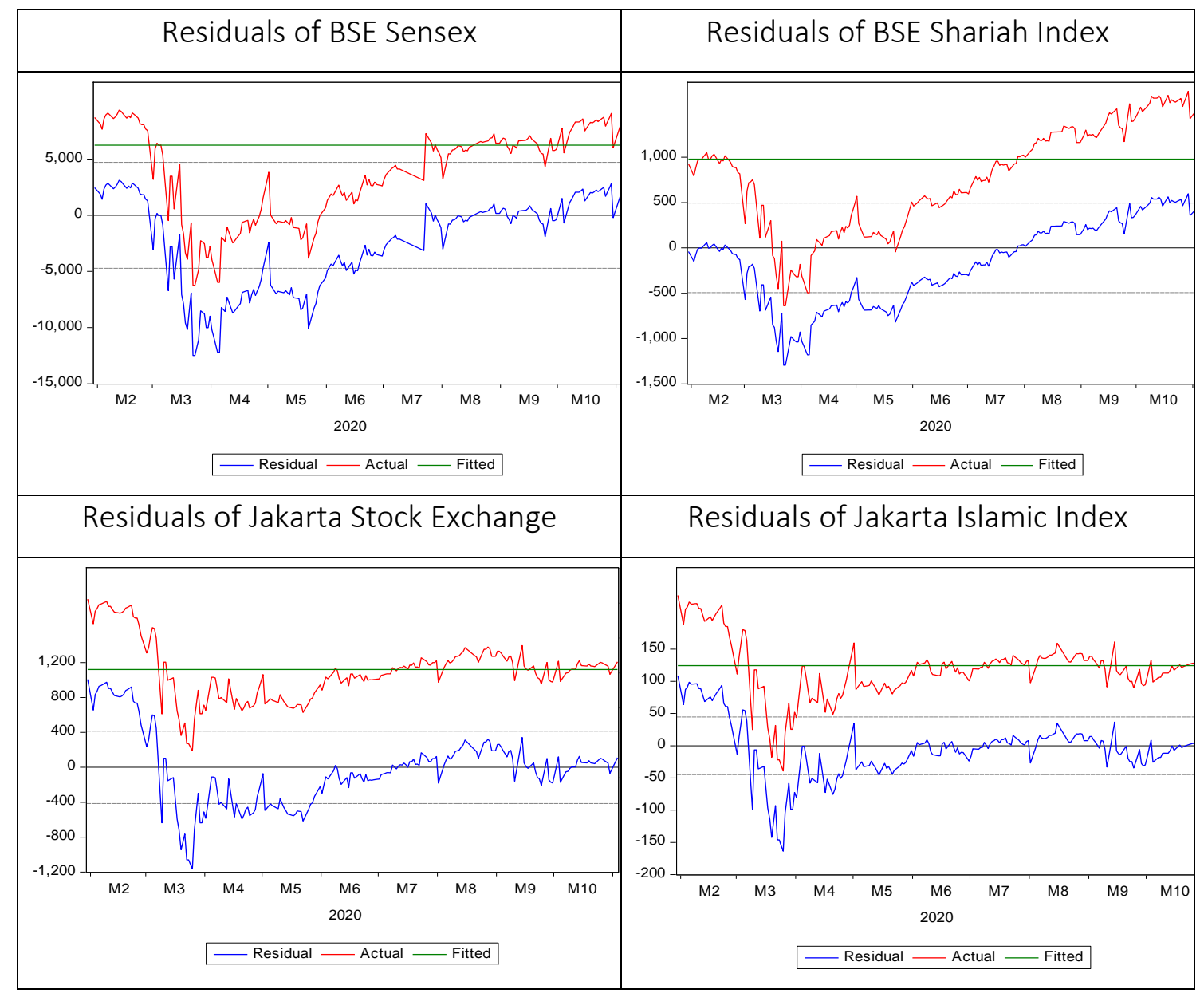

\subsection{Analysis}

The present study evaluates the impact of the WHO declaration of "Covid-19 as a Global Pandemic" on the stock market of India (BSE Sariah) \& Indonesia (III). The market model method of event study shows different direction result of Indian stock market \& Indonesian stock market. The results of BSE Sariah indices describe that the returns were already negative before the announcement. After the day of declaration, the Indian stock market returns move more downturns. All the three-event window-60days, 40days \& 20days results show a negative impact on the stock market of India. The outcomes of JII indices demonstrate upward positive movements for the Indonesian stock market. The declaration by WHO shows positive returns in all the three-event window of 60days, 40 days $\& 20$ days. The research found negative CAAR for BSE Sariah and positive CAAR for JII. Further, BSE Sariah \& JII indices results identify significant variance between market returns pre and post the announcement. The evolution and progress of any stock exchange depend on the robust economy of the country. That's why the result might vary for both 
Irfan, Kassim, \& Dhimmar | Impact of Covid-19 on Islamic Stock Markets: An Investigation using Threshold Volatility and Event Study Models

the country. In terms of India, investors take the WHO declaration negatively that was shown in the market reaction. The investors of Indonesia reacted positively to the WHO announcement that reflected on the stock market indices. However, the analyses of the present study cannot be generalized for other countries' stock exchange. It is also varying in different market environments or different periods in the future.

\section{Conclusion and Recommendation}

\subsection{Conclusion}

The coronavirus outbreak is impacted on whole world. India has major threat of coronavirus because it is the second largest country in terms of population. Likewise, other country face Covid-19 outbreak Indonesia too. The government of both the country take precautionary steps to deal with Covid19 situation. On 11 ${ }^{\text {th }}$ March 2020 WHO announce Covid-19 as Global Pandemic. The main purpose of this study is to identify impact of declaration of World Health Organization "Covid-19 as global pandemic" is impacted on stock market of India and Indonesia. The analyses of both the country shows different direction movement. It is drawn from the data analyses part that the reaction of stock market is varies for different countries. Like, Indian stock market shows downward sloping after the WHO declaration and Jakarta stock exchange shows upward sloping. The downturn graph of Indian stock exchange revealed that Indian stock market negatively reacted on WHO announcement. The upward graph of Jakarta stock exchange declares positive response to World Health Organization statement. The study concludes that semi-strong from of efficient market Hypothesis is true because market is efficient in processing its information and reacted on different economic situation. TARCH model is more suitable in BSE Shariah, Jakarta Islamic Indices. Meaning that more clearly effect of the bad news on the current market volatility.

\subsection{Recommendations}

The event study approach is very important in its own way. Like, in this study author analysed WHO declaration for Covid-19. The future research might be on different selected event window of Covid-19. Further, recent event like Presidential election of USA with Coronavirus pandemic can also be analyse. The study is only conducted for two countries- India \& Indonesia. Therefore, upcoming research of other countries on same event can give more prediction of Covid-19 impact globally. The countries may be G8, E7, and N11 or any country based on authors' research. It would recommend conducting a comparison study by taking additional worldwide samples. There is also the 
Irfan, Kassim, \& Dhimmar | Impact of Covid-19 on Islamic Stock Markets: An Investigation using Threshold Volatility and Event Study Models

possibility of a comparative study of a different pandemic. In the future, a longitudinal study may be fruitful to identify long-term impact. Further, demographic variables like gender, age, education, etc., will be studied in the stock market with the respective event. The variable corona death \& confirmed cases used in the present study in future other variables also incorporated to have a more valuable result. 
Irfan, Kassim, \& Dhimmar | Impact of Covid-19 on Islamic Stock Markets: An Investigation using Threshold Volatility and Event Study Models

\section{References}

Alali, M. S. (2020). The effect of who Covid-19 announcement on Asian stock markets returns: An event study analysis. Journal of Economics and Business, 3(3). https://doi.org/10.31014/aior.1992.03.03.261

Alam, M. N., \& Chavali, K. (2020). Stock market response during Covid-19 lockdown period in India: An event study. Journal of Asian Finance, Economics and Business, 7(7), 131-137. https://doi.org/10.13106/jafeb.2020.vol7.no7.131

Asia, S. (2020). India continues saving lives and livelihoods - recording more covid-19 recoveries while lifting restrictions. (November), 1-7.

Atsu, F., \& Prasad, R. (2020). Reaction of stock volatility to data breach: an event study. Journal of Cyber Security and Mobility, 9(3), 1-19. https://doi.org/10.13052/JCSM2245-1439.931

Bash, A. (2020). International evidence of covid-19 and stock market returns : an event study analysis. International Journal of Economics and Financial Issues, 10(4), 34-38. https://doi.org/10.32479/ijefi.9941

Case, B. (2018). Stock market reaction to monetary policy: An event study analysis of the stock market reaction to monetary policy : An event study analysis of the Brazilian case. Emerging Markets Finance and Trade, 54(11), 2577-2595. https://doi.org/10.1080/1540496X.2017.1364622

Chaudhary, R., Bakhshi, P., \& Gupta, H. (2020). Volatility in international stock markets: an empirical study during Covid-19. Journal of Risk and Financial Management, 13(9), 208. https://doi.org/10.3390/jrfm13090208

Chauhan, S. (2017). Impact of demonetization on stock market : Event study. Indian Journal of Accounting (IJA). Vol. XLIX (1), June, 2017, pp. 127-132.

Chavali, K., Alam, M. N., \& Rosario, S. (2020). Stock market response to elections : An event study method. Journal of Asian Finance Economics and Business. https://doi.org/10.13106/jafeb.2020.vol7.no5.009

Chong, T. T. L., Li, X., \& Yip, C. (2020). The impact of covid-19 on ASEAN. Economic and Political Studies, https://doi.org/10.1080/20954816.2020.1839166

Fama, E. F., Fisher, L., Jensen, M. C., \& Roll, R. (1969). The adjustment of stock prices to new information. International Economic Review, 10(1), 1. https://doi.org/10.2307/2525569

Gok, I. Y., \& Dayi, F. (2018). The effects of political uncertainty on the turkish stock market: An event study analysis. (pp. 191-196). Association of Economists and Managers of the Balkans - Udekom Balkan. https://doi.org/10.31410/eman.2018.191 
Irfan, Kassim, \& Dhimmar | Impact of Covid-19 on Islamic Stock Markets: An Investigation using Threshold Volatility and Event Study Models

Gunawardana, K. (2017). Stock Market reaction to Thaifex: An event study analysis. International Journal of the Computer, the Internet and Management, 13(2), 34-34.

Ibrahim, M. H. (2019). Oil and macro-financial linkages: Evidence from the GCC countries. The Quarterly Review of Economics and Finance, 72, 113.

Irfan, M. (2016). A Study of Islamic stock indices and macroeconomic variables. International Journal of Social, Behavioral, Educational, Economic, Business and Industrial Engineering, 10(7), 2557-2565.

Irfan, M. (2017). An empirical study of price discovery in commodities future market. Indian Journal of Finance, 11(3).

Irfan, M. (2020). Do Google trends and shariah compliant stocks cointegrated? an evidence from India. IJIEF: International Journal of Islamic Economics and Finance, 3(2), 1-17.

Jin, F., Wang, W., Chakraborty, P., Self, N., \& Chen, F. (2017). Tracking multiple social media for stock market event prediction. In Lecture Notes in Computer Science. Vol. 10357 LNAI, pp. 16-30. Springer Verlag. https://doi.org/10.1007/978-3-319-62701-4_2

Jonsson, R., \& Radeschnig, J. (2014). From market efficiency to event study methodology division of business and social sciences. 1-45. http://www.diva-portal.org/smash/get/diva2:727035/FULLTEXT01.pdf

Katsikides, S., Markoulis, S., \& Papaminas, M. (2016). Corporate social responsibility and stock market performance : an event study approach. International Journal of Engineering and Advanced Technology. Volume6, Issue-2.

Khatatbeh, I., Hani, M. A. B., \& Alfoul, M. A. (2020). The impact of covid-19 pandemic on global stock markets : an event study. International Journal of Economics and Business Administration. Volume VIII, Issue 4.

Kulal, A. (2020). Impact of coronavirus on indian stock market-an event study with reference to nifty 50. SSRN Electronic Journal. https://doi.org/10.2139/ssrn.3768419

Liu, C. (2020). Analysis of relationship between hot news and stock market based on Ida model and event study. In Journal of Physics: Conference Series (Vol. 1616). Institute of Physics Publishing. https://doi.org/10.1088/1742-6596/1616/1/012048

Market, S., \& Jung, H. (2020). Improved testing procedures for long-horizon event studies in the korean improved testing procedures for longhorizon event studies in the korean stock market. Asia-Pacific Journal of Financial Studies.

Meher, B. K., Hawaldar, I. T., Mohapatra, L., \& Sarea, A. M. (2020). The impact of covid-19 on price volatility of crude oil and natural gas listed on multi commodity exchange of India. International Journal of Energy Economics 
Irfan, Kassim, \& Dhimmar | Impact of Covid-19 on Islamic Stock Markets: An Investigation using Threshold Volatility and Event Study Models

and Policy, 10(5), 422-431. https://doi.org/10.32479/ijeep.10047

Methodology, E. S., Example, E. W., Benninga, S., Modeling, F., \& Benninga, F.-. (2020). Conducting event studies with excel. 2-3.

Nisar, T. M., \& Yeung, M. (2018). Twitter as a tool for forecasting stock market movements: a short-window event study. Journal of Finance and Data Science, 4(2), 101-119. https://doi.org/10.1016/j.jfds.2017.11.002

OECD. (2020). OECD Home About Countries. December, 1-36.

Panyagometh, K. (2020). The effects of pandemic event on the stock exchange of Thailand. Economies, 8(4), 90. https://doi.org/10.3390/economies8040090

Pérez-rodríguez, J. V, \& López-valcárcel, B. G. (2012). Does innovation in obesity drugs affect stock markets? an event study analysis. Gaceta Sanitaria, 26(4), 352-359. https://doi.org/10.1016/j.gaceta.2011.07.028

P.P., S. A., \& Deo, M. (2013). Modelling conditional volatility in shariah index of gcc countries. Singaporean Journal of business Economics, and management studies, 3(4), 22-31.

Research, E. S. (2003). Description abnormal return study. Princeton (1), 1-5.

Šafár, L., \& Sini, M. (2019). Quantitative easing effects on equity markets event study evidence from the US.E a M: Ekonomie a Management, 22(2), 173-187. https://doi.org/10.15240/tul/001/20192-012

Setiawan, B., Indo, U., \& Mandiri, G. (2020). Does US-China trade war matter on asean stock market: Event-study approach. Sriwijaya International Journal of Dynamic Economics And Business, 4(3), 161. https://doi.org/10.29259/sijdeb.v4i3.161-74

Shehzad, K., Xiaoxing, L., \& Kazouz, H. (2020). Since January 2020 Elsevier has created a COVID-19 resource centre with free information in English and Mandarin on the novel coronavirus COVID- 19. The COVID-19 resource centre is hosted on Elsevier Connect, the company' s public news and information. Diabetes Metab Syndr., 14(4)(January), 337-339.

Skrinjaric, T. (2019). Effects of change in stock market index composition on stock returns: event study metodology on zagreb stock exchange. Croatian Review of Economic, Business and Social Statistics (CREBSS), 5(1), 43-54.

Tahir, S. H., Tahir, F., Syed, N., Ahmad, G., \& Ullah, M. R. (2020). Stock market response to terrorist attacks : An event study approach. Journal of Asian Finance, Economics and Business, 7(9), 31-37. https://doi.org/10.13106/JAFEB.2020.VOL7.NO9.031.

TOI. (2020). Timespoints. Times of India, 2020, 1-17. https://timesofindia.indiatimes.com/business/internationalbusiness/imf-anticipates-worst-economic-growth-fallout-since-great- 
Irfan, Kassim, \& Dhimmar | Impact of Covid-19 on Islamic Stock Markets: An Investigation using Threshold Volatility and Event Study Models

depression/articlesho...

World Health Organisation (WHO). (2020, December 25). South-East Asia Region. Retrieved from https://www.who.int/countries/ind/: https://www.who.int/countries/ind/

Zhikun, Z. (2019). Event Study on lifting ban of restricted shares in Chinese stock markets. International Conference on Economic Management and Cultural Industry (Icemci), 861-867. 
Irfan, Kassim, \& Dhimmar | Impact of Covid-19 on Islamic Stock Markets: An Investigation using Threshold Volatility and Event Study Models

This page is intentionally left blank.

. International Journal of Islamic Economics and Finance (IJIEF), 4(1), 121-148 | 148 